\title{
PENGETAHUAN DAN SIKAP KELUARGA TENTANG JAMBAN SEHAT DI DESA GAYAMAN RT 1 RW 2 MOJOANYAR MOJOKERTO
}

\author{
Eka Diah Kartiningrum
}

\begin{abstract}
The health latrine is the room has facilitation to throw human dirty. The increasing of growth residents and the decreasing earning of society get caused by too difficult in latrine problem. There is also factor that causes society doesn't understand about latrine problem, because there is assumtion all of sanitation problem accord to government's matter. The aim of this research is to know about realtionship with family attitude about the healthy latrine in $R T 1 R W 2$ desa Gayaman Mojoanyar of Mojokerto. This research used by correlation design. Population research is all of families RT 1 RW 2 Desa Gayaman Mojoanyar of Mojokerto that amount of 44 "KK", and research sample is 38 " $K K$ " that are taken by simple random sampling. There are two variables in this research. They are independet variable and dependent variable. The first explain about knowledge of the health "jamban" dan the second explains family attitude to the healthy latrine". The result of this research anaylized uses chi square examination, where $X^{2}$ counting $>X^{2}$ table with $\alpha=0.05$ where $X^{2}$ counting $=7.56$ dan $X^{2}$ table $=5.591$ so Ho refused $\left(H_{1}\right.$ accepted) means that there is relationship between knowledge with family attitude for the health "jamban in RT1 RW2 Desa Gayaman of Mojokerto. The good knowledge will effects attitude, so the whole understanding in attitude, knowledge, confidence and emotion are very important in this problem. The conclusion is the most responder has good knowledge dan positive attitude hopely the family keep more health member of their family by keeping their environment and one of the attitude is to clean and keep latrine.
\end{abstract}

Key words: knowledge, attitude, latrine.

\section{A. PENDAHULUAN.}

Jamban merupakan fasilitas sanitasi dasar, terdapat 160 rumah yang memiliki jamban yang tidak memenuhi syarat kesehatan di kelurahan Bloto Mojokerto. Banyak juga jamban keluarga yang dibangun berdekatan dengan sumur yang selama ini dikonsumsi rumah tangga bersangkutan. Penampung jamban dapat merembes sampai ke dasar sumur sehingga air sumur terkontaminasi berbagai kotoran dan bakteri (Wulandari, 2009). Di wilayah perkotaan atau pedesaan dengan tata kelola ruang yang kurang tertata, masalah jamban masih merupakan permasalahan yang pelik dan belum seluruhnya dapat diatasi.

Penyakit yang timbul akibat kondisi jamban yang kotor yaitu diare, disentri, kolera, tipus, cacingan, malaria. Jamban sendiri merupakan tempat penampungan kotoran manusia yang sengaja dibuat untuk mengamankannya (Koordinator Program Kartunagari, 2008). Di Jakarta diperkirakan 35\% jamban yang tidak memiliki fasilitas air yang memadai, tidak memiliki atap, tidak tersambung ke septik tank. Sedangkan menurut survei EHRA tentang kondisi jamban di kota Tegal sekitar 6,9\% jamban yang memiliki tinja yang terlihat, 3,7\% terlihat terdapat lalat beterbangan, dan hanya sekitar $0,4 \%$ terlihat ada pembalut wanita di dalamnya. Hal tersebut menyebabkan kerugian yang tidak sedikit karena dapat menyebabkan tingginya bakteri patogen, jamur, cacing parasit (Prasetyo, 2003).

Tingginya angka pertumbuhan penduduk dan rendahnya pendapatan masyarakat menyebabkan semakin rumitnya masalah jamban. Disamping itu ada faktor yang menyebabkan masyarakat belum tahu tentang masalah jamban, karena ada anggapan bahwa semua urusan sanitasi merupakan urusan pemerintah. Masalah kesehatan lingkungan dapat muncul sebagai akibat rendahnya tingkat pendidikan penduduk. Sedangkan menurut studi pendahuluan yang dilakukan pada tanggal 4 Mei 2009 diantara $42 \mathrm{KK}, 5 \mathrm{KK}$ yang diamati mengetahui tentang jamban namun kurang memahami cara 
memeliharanya sehingga kondisi jamban yang mereka miliki kotor. Pengetahuan atau kognitif merupakan domain yang sangat penting untuk terbentuknya tindakan seseorang (overt behaviour) (Notoatmodjo, 2003). Pengetahuan mengenai suatu obyek yang baru akan menjadi sikap lebih baik apabila sikap tersebut di dasari pengetahuan (Purwanto, 1999). Masyarakat itu tidak tahu cara memelihara jamban dan tidak mau membersihkan sehingga masyarakat lupa bahwa kondisi jamban yang kotor dapat mengakibatkan segala macam penyakit (Mujianto, 2009).

Upaya-upaya pendekatan melalui penyuluhan kepada masyarakat, keluarga perlu dilakukan dengan melibatkan peran keluarga, masyarakat sebagai aktor penyelenggara dengan di dukung pemerintah sebagai fasilitatornya. Pemerintah terus mendukung masyarakat, keluarga dalam upaya meningkatkan sanitasi dasar sehingga dapat meningkatkan derajat kesehatan (Wulandari, 2009). Berdasarkan fenomena diatas, peneliti sangat tertarik untuk melakukan penelitian dengan judul masalah "Hubungan pengetahuan dengan sikap keluarga tentang jamban sehat di Desa Gayaman RT 1 RW 2 Kecamatan Mojoanyar Kabupaten Mojokerto".

\section{B. TINJAUAN PUSTAKA.}

1. Konsep Pengetahuan.

\section{a. Pengertian.}

Pengetahuan adalah merupakan hasil tahu dan ini terjadi setelah orang melakukan penginderaan terhadap suatu obyek tertentu sebagian besar pengetahuan manusia diperoleh melalui mata dan telinga. Pengetahuan atau kognitif merupakan domain yang sangat penting dalam membentuk tindakan seseorang (overt behavior) (Notoatmodjo, 2003). Dari beberapa pengertian di atas dapat di simpulkan bahwa pengetahuan merupakan hasil pengenalan panca indra terhadap suatu obyek tertentu.

b. Proses Pengambilan Pengetahuan.

Penelitian Rogers (1974) dalam Notoatmodjo (2003), mengungkapkan bahwa sebelum orang mengadopsi pengetahuan di dalam dirinya ada proses berurutan yakni :

1) Awareness (kesadaran), dimana orang tersebut menyadari dalam arti mengetahui terlebih dahulu terhadap stimulus (obyek).

2) Interest (merasa tertarik) terhadap stimulus atau obyek tersebut. Disini sikap subyek sudah mulai timbul.

3) Evaluation (menimbang-nimbang) terhadap baik dan tidaknya stimulus tersebut bagi dirinya. Hal ini berarti sikap responden sudah lebih baik lagi.

4) Trial, dimana subyek mulai mencoba melakukan sesuatu sesuai dengan apa yang dikehendaki oleh stimulus.

5) Adoption, di mana subyek telah berperilaku baru sesuai dengan pengetahuan, kesadaran, dan sikapnya terhadap stimulus.

c. Tingkat Pengetahuan.

Menurut Notoatmodjo (2003) tingkatan pengetahuan yang tercakup di dalam domain kognitif mempunyai 6 tingkat, yakni :

1) Tahu (know).

Tahu diartikan mengingat sesuatu yang telah dipelajari sebelumnya termasuk ke dalam pengetahuan ini adalah mengingat kembali (recall) terhadap sesuatu yang spesifik dari seluruh bahan yang dipelajari atau rangsangan yang telah diterima, oleh karena itu tahu merupakan tingkat pengetahuan yang paling rendah kata kerja yang mewakili adalah menyebutkan, menjodohkan, memilih.

2) Memahami (comprehension).

Memahami diartikan kemampuan menjelaskan secara benar tentang obyek yang diketahui dan dapat menginterpretasikan materi tersebut secara benar. Kata 
kerja operasional yang mewakili adalah menjelaskan, menguraikan, menyimpulkan dan lain-lain.

3) Aplikasi (aplication).

Aplikasi diartikan sebagai kemampuan untuk menggunakan materi yang dipelajari pada situasi dan kondisi yang sebenarnya. Aplikasi disini dapat diartikan aplikasi atau penggunaan hukum-hukum, rumus-rumus statistika dalam perhitungan hasil penelitian, prinsip dan sebagainya. Kata kerja operasional yang mewakili adalah mendemonstrasikan, menghubungkan, membuktikan, dan lain-lain.

4) Analisis (analisys).

Analisis adalah suatu kemampuan untuk menyebarkan suatu obyek atau materi atau materi-materi ke dalam komponen-komponen tetapi masih di dalam struktur organisasi tersebut dan masih ada kaitan satu sama lain. Kata kerja operasional yang mewakili adalah memisahkan, mempertentangkan, dan lainlain.

5) Sintesis (sinthesis).

Sintesis merupakan kemampuan untuk menyusun permulaan baru dari formulasi-formulasi yang ada. Kata kerja operasional yang mewakili adalah mengkategorikan, mengkombinasikan, menyusun, merangkaikan dan lain-lain.

6) Evaluasi (evaluation).

Evaluasi ini berkaitan dengan kemampuan untuk melakukan justifikasi atau penilaian terhadap suatu materi atau obyek. Kata kerja operasional yang mewakili adalah memperbandingkan, membahas, memberikan argumentasi dan lain-lain.

d. Faktor-faktor yang mempengaruhi pengetahuan :

Faktor-faktor yang mempengaruhi pengetahuan adalah :

1) Pendidikan.

Pendidikan berarti bimbingan yang diberikan seseorang pada orang lain terhadap sesuatu hal agar mereka dapat memahami. Tidak dapat dipungkiri bahwa makin tinggi pendidikan seseorang semakin mudah pula mereka menerima informasi, dan pada akhirnya makin banyak pula pengetahuan yang dimilikinya. Sebaliknya jika seseorang tingkat pendidikannya rendah, akan menghambat perkembangan sikap seseorang terhadap penerimaan, informasi dan nilai-nilai yang baru diperkenalkan (Mubarrak, 2007).

2) Pekerjaan.

Lingkungan pekerjaan dapat menjadikan seseorang memperoleh pengalaman dan pengetahuan baik secara langsung maupun secara tidak langsung (Mubarrak, 2007).

3) Umur.

Elizabet B, H (1995) mengatakan bahwa makin tua umur seseorang, maka proses perkembangan akan bertambah baik, akan tetapi pada umur-umur tertentu bertambahnya proses perkembangan mental ini tidak secepat seperti ketika berumur belasan tahun. Dewasa penuh merupakan masa penyesuaian terhadap pola-pola kehidupan dan harapan sosial yang baru. Ini menunjukkan bahwa pada masa dewasa penuh sangat banyak problematika dan tuntutan yang harus dikerjakan oleh kaum dewasa, sehinggga secara tidak langsung hal ini akan menurunkan konsentrasi. Usia dewasa penuh, dimana pada usia ini merupakan kelanjutan dari masa remaja, dimana ciri yang menonjol nampak dalam adanya peletakan dasar dalam banyak aspek kehidupan (settling down age), usia yang banyak masalah (problem age), merupakan usia tegang dalam hal emosi (Mappiare, 1983). 
4) Minat.

Sebagai suatu kecenderungan atau keinginan yang tinggi terhadap sesuatu. Minat menjadikan seseorang untuk mencoba dan menekuni suatu hal dan pada akhirnya diperoleh pengetahuan yang lebih mendalam (Mubarrak, 2007).

5) Pengalaman.

Suatu kejadian yang pernah dialami seseorang dalam berinteraksi dengan lingkungannya. Ada kecenderungan pengalaman yang kurang baik seseorang akan berusaha untuk melupakan, namun jika pengalaman terhadap obyek tersebut menyenangkan maka secara psikologis akan timbul kesan yang sangat mendalam dan membekas dalam emosi kejiwaannya, dan akhirnya dapat pula membentuk sikap positif dalam kehidupannya (Mubarrak, 2007).

6) Kebudayaan lingkungan sekitar.

Kebudayaan dimana kita hidup dan dibesarkan mempunyai pengaruh besar terhadap pembentukan sikap kita. Apabila dalam suatu wilayah mempunyai budaya untuk menjaga kebersihan lingkungan maka sangat mungkin masyarakat sekitar mempunyai sikap untuk selalu menjaga kebersihan lingkungan, karena lingkungan sangat berpengaruh dalam pembentukan sikap pribadi atau sikap seseorang (Mubarrak, 2007).

7) Informasi.

Kemudahan unutk memperoleh suatu informasi dapat membantu mempercepat seseorang untuk memperoleh pengetahuan yang baru (Mubarrak, 2007).

e. Cara memperoleh pengetahuan.

Berbagai macam cara yang telah digunakan untuk memperoleh kebenaran pengetahuan sepanjang sejarah, dapat dikelompokkan menjadi 2, yaitu cara tradisonal (non ilmiah) dan cara modern (ilmiah).

1) Cara tradisional (non ilmiah).

Cara tradisional ini dipakai orang untuk memperoleh kebenaran pengetahuan sebelum ditemukannya metode ilmiah atau metode penemuan secara sistematis dan logis. Cara-cara penemuan pengetahuan secara tradisional antara lain :

a) Coba dan salah (trial and error).

Cara ini telah dipakai orang sebelum adanya kebudayaan, bahkan mungkin sebelum adanya peradaban. Cara ini dilakukan dengan menggunakan kemungkinan dalam memecahkan masalah. Apabila kemungkinan tersebut tidak berhasil maka akan di coba dengan kemungkinan yang lain (Notoatmodjo, 2005).

b) Cara kekuasaan (otoritas).

Prinsip dalam cara ini adalah orang lain menerima pendapat yang dikemukakan oleh orang yang mempunyai aktivitas tanpa menguji atau membuktikan kebenaran terlebih dahulu, baik berdasarkan fakta empiris atau berdasarkan penalaran sendiri (Notoatmodjo, 2005).

c) Berdasarkan pengalaman pribadi.

Pengalaman merupakan sumber pengetahuan atau merupakan suatu cara untuk memperoleh kebenaran pengetahuan. Dilakukan dengan cara pengulangan kembali pengalaman pribadi, dapat menuntut seseorang untuk menarik kesimpulan dengan benar. Untuk menarik kesimpilan dari pengalaman dengan benar diperlukan berpikir secara logis (Notoatmodjo, 2005).

d) Cara jalan pikir.

Dalam memperoleh kebenaran pengetahuan manusia telah menggunakan jalan pikirannya baik melalui induksi maupun deduksi (Notoatmodjo, 2005). 
2) Cara modern (ilmiah).

Cara baru atau modern dalam memperoleh pengetahuan pada saat ini, lebih sistematis, logis dan ilmiah untuk memperoleh kesimpulan dilakukan dengan jalan mengadakan observasi langsung dan membuat pencatatan-pencatatan terhadap semua fakta sehubungan dengan obyek penelitian (Notoatmodjo, 2005).

\section{Konsep Dasar Sikap.}

a. Pengertian Sikap.

Sikap merupakan reaksi atau respon seseorang yang masih tertutup terhadap suatu stimulus atau obyek (Notoatmodjo, 2003). Sikap adalah suatu bentuk evaluasi atau reaksi perasaan. Sikap seseorang terhadap suatu obyek adalah perasaan mendukung atau memihak (favorable) maupun perasaan tidak mendukung atau memihak (unfavorable) pada obyek tersebut (Azwar, 2005).

Menurut Purwanto (1999), sikap merupakan pandangan tetapi dalam satu hal itu masih berbeda dengan pengetahuan yang dimiliki orang. Pengetahuan suatu obyek tidak sama dengan sikap terhadap obyek itu. Pengetahuan saja belum bisa menjadi penggerak, seperti halnya pada sikap. Pengetahuan mengenai suatu obyek yang baru akan menjadi sikap lebih baik apabila sikap tersebut di dasari pengetahuan. Jadi pengetahuan seseorang juga bisa berhubungan dengan sikap seseorang dengan berpengetahuan baik maka kecenderungan sikap orang tersebut baik juga atau positif.

b. Pembentukan Sikap.

Sikap sosial terbentuk adanya interaksi sosial, terjadi hubungan saling mempengaruhi diantara individu yang satu dengan yang lain, terjadi hubungan timbal balik yang turut mempengaruhi pola perilaku masing-masing individu sebagai anggota masyarakat (Azwar, 2005). Faktor-faktor yang mempengaruhi dalam pembentukan sikap adalah :

1) Pengalaman pribadi.

Pengalaman yang dialami setiap individu akan membentuk dan mempengaruhi penghayatan kita terhadap situasi sosial. Tanggapan akan menjadi salah satu dasar terbentuknya sikap. Pengalaman yang berkaitan dengan obyek psikologis akan mempunyai penghayatan itu membentuk sikap positif atau sikap negatif, akan tergantung pada setiap faktor lain (Azwar, 2005).

2) Pengaruh orang lain.

Orang lain disekitar kita merupakan salah satu diantara komponen sosial yang ikut mempengaruhi sikap kita. Seseorang yang kita anggap penting akan banyak mempenagruhi sikap kita terhadap sesuatu (Azwar, 2005).

3) Pengaruh kebudayaan.

Kita memiliki pola sikap dan perilaku tertentu dikarenakan kita mendapat reinforcement (penguatan dan ganjaran) dari masyarkat untuk sikap dan perilaku tersebut, bukan untuk sikap dan perilaku yang lain (Azwar, 2005).

4) Media massa.

Media massa sebagai sarana komunikasi mempunyai pengaruh besar dalam pembentukan opini dan kepercayaan orang (Azwar, 2005).

5) Lembaga pendidikan dan lembaga agama.

Lembaga pendidikan dan lembaga agama sebagai suatu sistem mempunyai pengaruh dalam pembentukan sikap dikarenakan keduanya meletakkan dasar pengertian dan konsep moral dalam individu (Azwar, 2005).

c. Komponen Sikap.

Allport dalam Notoatmojo (2003) menyatakan bahwa sikap mempunyai 3 komponen pokok yaitu : 
1) Kepercayaan (keyakinan), ide dan konsep suatu obyek.

2) Kehidupan emosional atau evaluasi emosional terhadap suatu obyek.

3) Kecenderungan untuk bertindak.

Ketiga komponen tersebut secara bersama-sama membentuk sikap yang utuh. Dalam penentuan sikap yang utuh ini pengetahuan, berpikir, keyakinan dan emosi memegang peranan penting.

d. Tingkatan Sikap.

Seperti halnya dengan pengetahuan, sikap ini terdiri dari berbagai tingkatan (Notoatmodjo, 2003) yaitu:

1) Menerima (receiving).

Menerima diartikan orang (subyek) mau dan memperhatikan stimulus yang diberikan (obyek).

2) Merespon (responding).

Memberikan jawaban apabila ditanya, mengerjakan dan menyelesaikan tugas dan diberikan adalah suatu indikasi dari sikap. Karena dengan suatu usaha untuk menjawab pertanyaan atau mengerjakan tugas yang diberikan, terlepas dari pekerjaan itu benar atau salah adalah berarti bahwa orang menerima ide tersebut.

3) Menghargai (valuing).

Mengajak orang lain untuk mengerjakan atau mendiskusikan suatu masalah adalah suatu indikasi.

4) Bertanggung jawab (responsible).

Bertanggung jawab atas segala sesuatu yang telah dipilihnya dengan segala resiko merupakan sikap yang paling tinggi.

\section{Konsep Dasar Keluarga.}

a. Pengertian.

Menurut Departemen Kesehatan dalam Danang (2008) Keluarga adalah unit terkecil dalam masyarakat yang terdiri atas kepala keluarga, dan beberapa orang yang berkumpul dan tinggal disuatu tempat dibawah satu atap dalam keadaan saling ketergantungan, sedangkan menurut Friedman dalam Suprajitno (2004) Keluarga adalah kumpulan dua orang atau lebih yang hidup bersama dengan keterikatan aturan dan emosional dan individu mempunyai peran masing-masing yang merupakan bagian dari keluarga.

b. Fungsi Keluarga, menurut Effendy 1998 dalam Danang (2008) ada 5 yaitu :

1) Fungsi Biologis.

a) Untuk meneruskan keturunan.

b) Memelihara dan membesarkan anak.

c) Memenuhi kebutuhan gizi keluarga.

d) Memelihara dan merawat anggota keluarga.

2) Fungsi Ekonomi.

a) Mencari sumber-sumber penghasilan untuk memenuhi kebutuhan keluarga.

b) Pengaturan penggunaan penghasilan keluarga untuk memenuhi kebutuhan keluarga.

c) Menabung untuk memenuhi kebutuhan-kebutuhan keluarga dimasa yang akan datang misalnya pendidikan anak, jaminan hari tua dan sebagainya.

3) Fungsi Pendidikan.

a) Menyekolahkan anak untuk memberikan pengetahuan, keterampilan dan membentuk perilaku anak sesuai dengan bakat dan minat yang dimilikinya.

b) Mempersiapkan anak untuk hidup dewasa yang akan datang dalam memenuhi peranannya sebagai orang dewasa.

c) Mendidik anak sesuai dengan tingkat-tingkat perkembangannya. 
4) Fungsi Psikologis.

a) Memberi kasih sayang dan rasa aman.

b) Memberikan perhatian diantara anggota keluarga.

c) Membina pendewasaan kepribadiaan anggota keluarga.

5) Memberikan identitas keluarga. Fungsi Sosialisasi

a) Membina sosialisasi pada anak.

b) Membentuk norma-norma tingkah laku sesuai dengan tingkat perkembangan anak.

c) Meneruskan nilai-nilai budaya keluarga.

c. Ada 5 tugas keluarga dibidang kesehatan menurut Suprayitno (2004) dalam Danang (2008) keluarga mempunyai tugas dibidang kesehatan yang perlu dipahami dan dilakukan meliputi :

1) Mengenal masalah kesehatan keluarga.

Orang tua perlu mengenal keadaan kesehatan dan perubahan-perubahan yang dialalmi anggota keluarga. Perubahan sekecil apapun yang dialami anggota keluarga secara tidak langsung menjadi perhatian orang tua atau keluarga.

2) Memutuskan tindakan yang tepat bagi keluarga.

Tugas ini merupakan upaya keluarga yang utama untuk mencari pertolongan yang tepat sesuai dengan keadaan keluarga, dengan pertimbangan siapa diantara keluarga yang mempunyai kemampuan memutuskan untuk menentukan tindakan keluarga. Tindakan kesehatan yang dilakukan oleh keluarga diharapkan tepat agar masalah kesehatan dapat dikurangi atau bahkan diatasi.

3) Merawat keluarga yang mengalami gangguan kesehatan.

4) Memodifikasi lingkungan yang nyaman untuk jaminan kesehatan keluarga.

5) Memanfaatkan fasilitas kesehatan.

Menurut Friedman (1981) dalam Yenichrist (2008) untuk dapat mencapai tujuan asuhan keperawatan kesehatan keluarga, keluarga mempunyai tugas dalam pemeliharaan kesehatan para anggotanya dan saling memelihara, antara lain :

1) Mengenal gangguan perkembangan kesehatan setiap anggota keluarga.

2) Mengambil keputusan untuk melakukan tindakan yang tepat.

3) Memberikan keperawatan kepada anggota keluarganya yang sakit, dan yang tidak dapat membantu dirinya sendiri karena cacat atau usianya yang terlalu muda.

4) Mempertahankan suasana di rumah yang menguntungkan kesehatan dan perkembangan kepribadian anggota keluarga.

5) Mempertahankan hubungan timbal balik antara keluarga dan lembaga-lembaga kesehatan, yang menunjukkan pemanfaatan dengan baik fasilitas-fasilitas kesehatan yang ada.

\section{Konsep Jamban.}

a. Pengertian.

Jamban sehat adalah suatu ruangan yang mempunyai fasilitas pembuangan kotoran manusia yang terdiri atas tempat jongkok atau tempat duduk dengan leher angsa atau tanpa leher angsa (cemplung) yang dilengkapi dengan unit penampungan kotoran dan air untuk membersihkannya (DepKes RI, 2007).

b. Jenis Jamban.

1) Jamban cemplung adalah jamban yang penampungannya berupa lubang yang berfungsi menyimpan dan meresapkan cairan kotoran atau tinja ke dalam tanah dan mengendapkan kotoran ke dasar lubang. Untuk jamban cemplung diharuskan ada penutup agar tidak berbau.

2) Jamban tangki septik atau leher angsa adalah jamban berbentuk lehar angsa yang penampungannya berupa tangki septik kedap air yang berfungsi sebagai wadah 
proses penguraian atau dekomposisi kotoran manusia yang dilengkapi dengan resapannya (DepKes RI,2007).

c. Syarat jamban sehat menurut DepKes RI (2007) adalah sebagai berikut :

1) Tidak mencemari sumber air minum (jarak antara sumber air minum dengan lubang penampung minimal 10 meter).

2) Tidak berbau.

3) Kotoran tidak dapat dijamah oleh serangga dan tikus.

4) Tidak mencemari tanah disekitarnya.

5) Mudah dibersihkan dan aman digunakan.

6) Dilengkapi dinding dan atap pelindung.

7) Penerangan dan ventilasi cukup.

8) Lantai kedap air dan luas ruangan memadai.

9) Tersedia air, sabun, dan alat pembersih.

d. Cara memelihara jamban sehat menurut DepKes RI (2007) adalah sebagai berikut :

1) Lantai jamban hendaknya selalu bersih dan tidak ada genangan air.

2) Bersihkan jamban secara teratur sehingga ruang jamban dalam keadaan bersih.

3) Di dalam jamban tidak ada kotoran yang terlihat.

4) Tidak ada serangga, (kecoa, lalat) dan tikus yang berkeliaran.

5) Tersedia alat pembersih (sabun, sikat, dan alat pembersih).

6) Bila ada kerusakan segera perbaiki.

e. Manfaat jamban.

1) Menjaga lingkungan bersih, sehat, dan tidak bau.

2) Tidak mencemari sumber air yang ada disekitarnya.

3) Tidak mengundang datangnya lalat atau serangga yang dapat menjadi penular penyakit diare, disentri, typus, penyakit saluran pencernaan, penyakit kulit dan keracunan (Depkes RI, 2007).

\section{Kerangka Konseptual.}

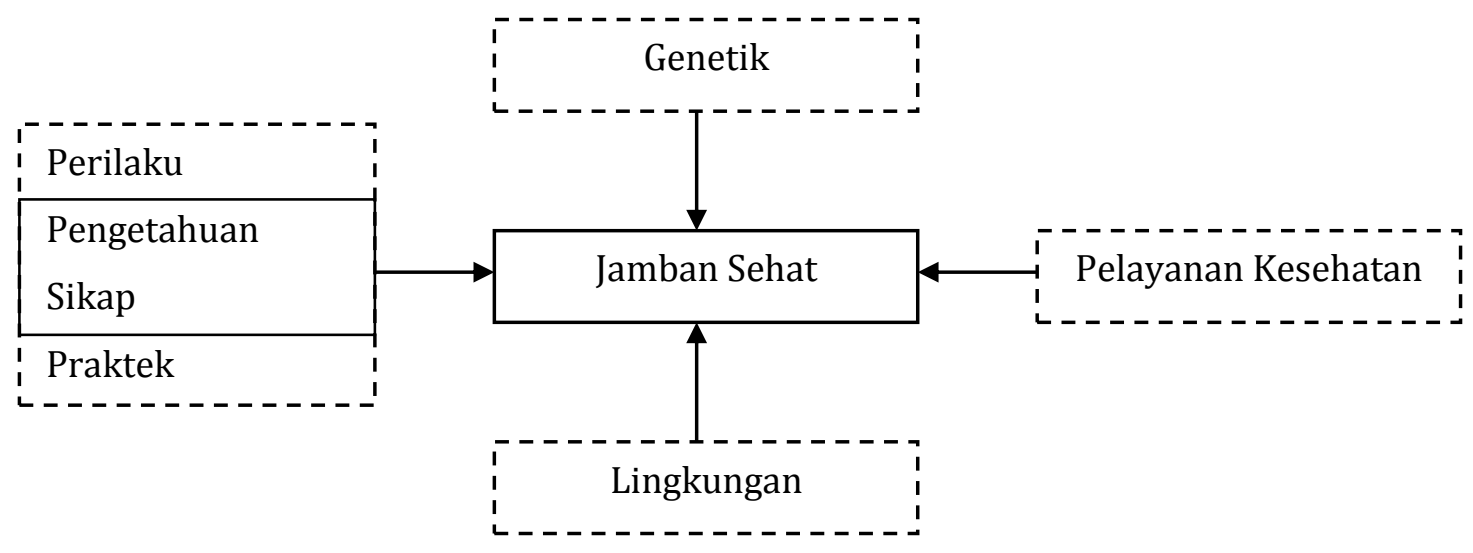

Gambar 1. Faktor-Faktor Yang Mempengaruhi Terwujudnya Jamban Sehat

\section{METODE PENELITIAN.}

1. Desain Penelitian.

Jenis penelitian yang dilaksanakan adalah penelitian korelasional yaitu penelitian yang digunakan untuk mengkaji hubungan antara variabel, peneliti dapat mencari, menjelaskan suatu hubungan, memperkirakan, menguji berdasarkan teori yang ada (Nursalam, 2003). 


\section{KERANGKA KERJA}

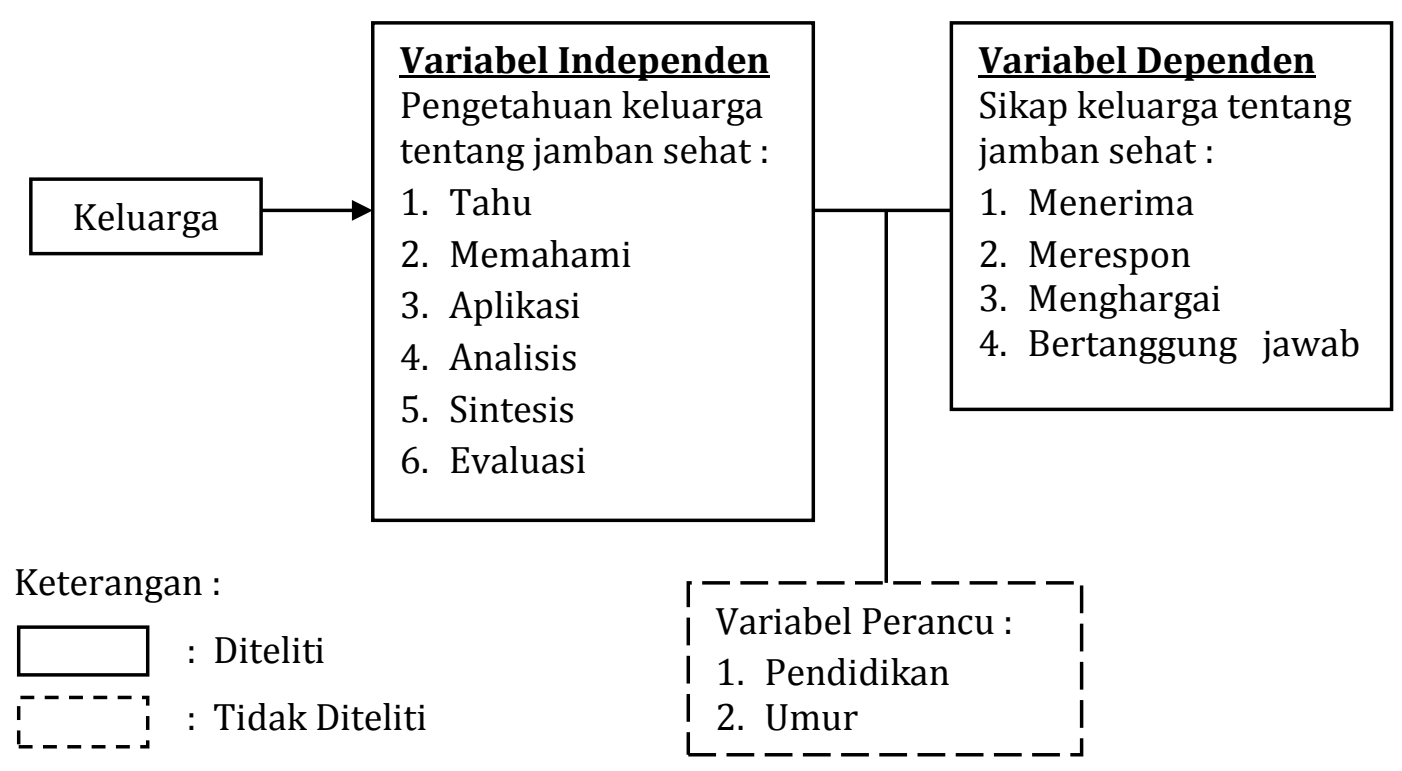
Gambar 2. Kerangka Kerja Hubungan Pengetahuan Dengan Sikap Keluarga Tentang Jamban Sehat di RT 1 RW 2 Desa Gayaman Mojoanyar Mojokerto

\section{Hipotesis.}

$\mathrm{H}_{1}$ : Ada hubungan antara pengetahuan dengan sikap keluarga tentang jamban sehat.

Ho : Tidak ada hubungan antara penegtahuan dengan sikap keluarga tentang jamban sehat.

3. Populasi, Sampel, Variabel, Instrumen Penelitian, dan Definisi Operaisonal.

Populasi dalam penelitian ini adalah seluruh keluarga RT 1 RW 2 Desa Gayaman Mojoanyar Mojokerto, yaitu sebanyak $42 \mathrm{KK}$. Dalam penelitian ini sampel yang digunakan dipilih secara acak yang berjumlah $38 \mathrm{KK}$, yaitu yang memenuhi kriteria inklusi :

a. Warga RT 1 RW 2 Desa Gayaman Mojoanyar Mojokerto yang bersedia menjadi responden.

b. Warga RT 1 RW 2 Desa Gayaman Mojoanyar Mojokerto yang tidak buta huruf dan bisa baca tulis.

c. Warga RT 1 RW 2 Desa Gayaman Mojoanyar Mojokerto yang sudah menikah.

Penelitian ini menggunakan teknik probability sampling yaitu pengambilan sampel secara acak, prosedur pengambilan sampel menggunakan simple random sampling adalah pengambilan sampel secara acak tanpa memperhatikan strata yang ada dalam anggota populasi. Cara ini dilakukan bila anggota populasi dianggap homogen (Hidayat, 2003).

Variabel independen yang digunakan dalam penelitian ini adalah pengetahuan tentang jamban sehat, sedangkan variabel dependennya yaitu sikap keluarga tentang jamban sehat. 
Tabel 1. Definisi Operasional Hubungan Pengetahuan Dengan Sikap Keluarga Tentang Jamban Sehat di RT 1 RW 2 Desa Gayaman Mojoanyar Mojokerto

\begin{tabular}{|c|c|c|c|}
\hline Variabel & Definisi Operasional & Kriteria & Skala \\
\hline $\begin{array}{l}\text { Pengetahuan } \\
\text { keluarga tentang } \\
\text { jamban sehat }\end{array}$ & $\begin{array}{l}\text { Mengingat kembali terhadap } \\
\text { sesuatu rangsangan yang telah } \\
\text { diterima tentang jamban sehat: } \\
\text { 1. Pengertian jamban sehat } \\
\text { 2. Jenis jamban } \\
\text { 3. Syarat jamban sehat } \\
\text { 4. Cara memelihara jamban sehat } \\
\text { 5. Manfaat jamban }\end{array}$ & $\begin{array}{l}\text { Pengetahuan } \\
\text { keluarga tentang } \\
\text { jamban sehat: } \\
\text { Baik : } 76-100 \% \\
\text { Cukup : } 56-75 \% \\
\text { Kurang : }<56 \% \\
\text { (Nursalam, } 2003 \text { ) }\end{array}$ & Ordinal \\
\hline $\begin{array}{l}\text { Sikap keluarga } \\
\text { tentang jamban } \\
\text { sehat }\end{array}$ & $\begin{array}{l}\text { Evaluasi atau reaksi perasaan } \\
\text { keluarga disertai dengan tindakan } \\
\text { mau dan memberikan jawaban } \\
\text { apabila ditanya, menyelesaikan } \\
\text { dan mengerjakan tugas yang } \\
\text { diberikan. }\end{array}$ & $\begin{array}{l}\text { Positif jika } \mathrm{T}>50 \\
\text { Negatif jika } \mathrm{T} \leq 50 \\
\text { (Azwar, 2005) }\end{array}$ & Nominal \\
\hline
\end{tabular}

\section{Teknik Analisis Data.}

Penelitian ini menggunakan analisa bivariant. Data yang di dapat kemudian di uji chi square, dengan rumus chi square:

$$
\mathrm{X}^{2}=\frac{\sum\left(\mathrm{f}_{\mathrm{o}}-\mathrm{f}_{\mathrm{e}}\right)^{2}}{\mathrm{f}_{\mathrm{e}}}
$$

Keterangan : $\mathrm{X}^{2}=$ chi square

$\mathrm{f}_{\mathrm{o}}=$ frekuensi yang diobservasi

$\mathrm{f}_{\mathrm{e}} \quad=$ frekuensi yang diharapkan

mencari nilai $\mathrm{X}^{2}$ tabel dengan rumus :

$$
\mathrm{dk}=(\mathrm{k}-1)(\mathrm{b}-1)
$$

Keterangan : $\mathrm{k}=$ banyaknya kolom

$\mathrm{b}$ = banyaknya baris (Hidayat, 2007).

Jika $\mathrm{X}^{2}$ hitung $>\mathrm{X}^{2}$ tabel dengan $\alpha=0,05$ dan $\mathrm{dk}=(\mathrm{b}-1)(\mathrm{k}-1)$ dengan nilai $\mathrm{X}^{2}$ tabel adalah 5,591 maka Ho ditolak $\left(\mathrm{H}_{1}\right.$ diterima) sehingga terdapat hubungan dan sebaliknya apabila $\mathrm{X}^{2}$ hitung $<\mathrm{X}^{2}$ tabel maka Ho diterima $\left(\mathrm{H}_{1}\right.$ ditolak) sehingga tidak terdapat hubungan.

D. HASIL PENELITIAN.

1. Data Umum.

a. Karakteristik Responden Berdasarkan Umur.

Tabel 2. Karakteristik Umur Responden di RT 1 RW 2 Desa Gayaman

\begin{tabular}{|c|c|c|c|}
\hline No. & Karakteristik Umur & Frekuensi & Prosentase (\%) \\
\hline 1 & 20-24 tahun & 1 & 2,6 \\
\hline 2 & 25-60 tahun & 37 & 97,4 \\
\hline & Total & 38 & 100 \\
\hline
\end{tabular}
Mojoanyar Mojokerto

Tabel 2 menunjukkan bahwa mayoritas responden berumur 25-60 tahun dan sisanya berumur 20-24 tahun. 
b. Karakteristik Responden Berdasarkan Pendidikan.

Tabel 3. Karakteristik Pendidikan Responden di RT 1 RW 2 Desa Gayaman Mojoanyar Mojokerto

\begin{tabular}{|c|c|c|c|}
\hline No. & Karakteristik Pendidikan & Frekuensi & Prosentase (\%) \\
\hline 1 & SD & 12 & 31,6 \\
\hline 2 & SMP & 12 & 31,6 \\
\hline 3 & SMA & 14 & 36,8 \\
\hline \multicolumn{2}{|c|}{ Total } & 38 & 100 \\
\hline
\end{tabular}

Tabel 3 diketahui bahwa paling banyak responden berpendidikan SMA sedangkan responden dengan tingkat pendidikan SD dan SMP mempunyai proporsi yang paling kecil.

2. Data Khusus.

a. Pengetahuan Keluarga Tentang Jamban Sehat.

Tabel 4. Pengetahuan Keluarga Tentang Jamban Sehat di RT 1 RW 2 Desa Gayaman Mojoanyar Mojokerto

\begin{tabular}{|c|c|c|c|}
\hline No. & Pengetahun & Frekuensi & Prosentase (\%) \\
\hline 1 & Baik & 14 & 36,8 \\
\hline 2 & Cukup & 12 & 31,6 \\
\hline 3 & Kurang & 12 & 31,6 \\
\hline \multicolumn{2}{|r|}{ Total } & 38 & 100 \\
\hline
\end{tabular}

Tabel 4 menujukkan bahwa paling banyak responden memiliki pengetahuan baik sedangkan responden yang memiliki pengetahuan yang cukup dan kurang tentang jamban sehat mempunyai proposi yang sama kecil.

Tabel 5. Tabulasi Silang Antara Umur Dan Pengetahuan di RT 1 RW 2 Desa Gayaman Mojoanyar Mojokerto

\begin{tabular}{|c|c|c|c|c|c|c|c|c|c|}
\hline \multirow{3}{*}{ No. } & \multirow{3}{*}{ Umur } & \multicolumn{6}{|c|}{ Pengetahuan } & \multirow{2}{*}{\multicolumn{2}{|c|}{ TOTAL }} \\
\hline & & \multicolumn{2}{|c|}{ Baik } & \multicolumn{2}{|c|}{ Cukup } & \multicolumn{2}{|c|}{ Kurang } & & \\
\hline & & $\mathbf{F}$ & (\%) & $\mathbf{F}$ & (\%) & $\mathbf{F}$ & (\%) & $\mathbf{F}$ & $(\%)$ \\
\hline 1 & 20-24 tahun & 1 & 7,7 & 0 & 0 & 0 & 0 & 1 & 2,6 \\
\hline 2 & 25-60 tahun & 12 & 92,3 & 13 & 100 & 12 & 100 & 37 & 97,4 \\
\hline & Jumlah & 13 & 100 & 13 & 100 & 12 & 100 & 38 & 100 \\
\hline
\end{tabular}

Tabel 5 menunjukkan bahwa mayoritas responden berumur 25-60 tahun sedangkan responden yang mempunyai umur 20-24tahun mempunyai proporsi yang paling kecil.

Tabel 6. Tabulasi Silang Antara Pendidikan Dan Pengetahuan di RT 1 RW 2 Desa Gayaman Mojoanyar Mojokerto

\begin{tabular}{|c|c|c|c|c|c|c|c|c|c|}
\hline \multirow{3}{*}{ No. } & \multirow{3}{*}{ Pendidikan } & \multicolumn{6}{|c|}{ Pengetahuan } & \multirow{2}{*}{\multicolumn{2}{|c|}{ TOTAL }} \\
\hline & & \multicolumn{2}{|c|}{ Baik } & \multicolumn{2}{|c|}{ Cukup } & \multicolumn{2}{|c|}{ Kurang } & & \\
\hline & & $\mathbf{F}$ & (\%) & $\mathbf{F}$ & $(\%)$ & $\mathbf{F}$ & $(\%)$ & $\mathbf{F}$ & $(\%)$ \\
\hline 1 & SD & 0 & 0 & 0 & 0 & 12 & 100 & 12 & 31,6 \\
\hline 2 & SMP & 3 & 21,4 & 9 & 75 & 0 & 0 & 12 & 31,6 \\
\hline 3 & SMA & 11 & 78,6 & 3 & 25 & 0 & 0 & 14 & 36,8 \\
\hline & Jumlah & 13 & 100 & 13 & 100 & 12 & 100 & 38 & 100 \\
\hline
\end{tabular}

Tabel 6 menunjukkan bahwa semua responden yang berpendidikan SD mempunyai pengetahuan yang kurang tentang jamban sehat sedangkan responden dengan tingkat pendidikan SMP dan SMA tidak ada yang mempunyai pengetahuan yang kurang tentang jamban sehat. 
b. Sikap Keluarga Tentang Jamban Sehat.

Tabel 7. Sikap Keluarga Tentang Jamban Sehat di RT 1 RW 2 Desa Gayaman Mojoanyar Mojokerto

\begin{tabular}{|c|c|c|c|}
\hline No. & Sikap & Frekuensi & Prosentase (\%) \\
\hline 1 & Positif & 21 & 55,3 \\
\hline 2 & Negatif & 17 & 44,7 \\
\hline & Total & 38 & 100 \\
\hline
\end{tabular}

Tabel 7 menunjukkan bahwa lebih dari $50 \%$ responden memiliki sikap negatif terhadap jamban sehat sedangkan sisanya mempunyai sikap yang positif terhadap jamban sehat.

Tabel 8. Tabulasi Silang Antara Pendidikan Dan Sikap di RT 1 RW 2 Desa Gayaman Mojoanyar Mojokerto

\begin{tabular}{|c|c|c|c|c|c|c|c|}
\hline \multirow{2}{*}{ No. } & \multirow{2}{*}{ Pendidikan } & \multicolumn{4}{|c|}{ Sikap } & \multicolumn{2}{|c|}{ TOTAL } \\
\cline { 3 - 7 } & & \multicolumn{2}{|c|}{ Positif } & \multicolumn{2}{|c|}{ Negatif } & \multicolumn{2}{|c|}{ TO } \\
\cline { 2 - 7 } & F & $\mathbf{( \% )}$ & $\mathbf{F}$ & $\mathbf{( \% )}$ & $\mathbf{F}$ & $\mathbf{( \% )}$ \\
\hline 1 & SD & 3 & 14,3 & 9 & 53 & 12 & 31,6 \\
\hline 2 & SMP & 6 & 28,6 & 6 & 35,3 & 12 & 31,6 \\
\hline 3 & SMA & 12 & 57,1 & 2 & 11,7 & 14 & 36,8 \\
\hline \multicolumn{2}{|c|}{ Jumlah } & 21 & 100 & 17 & 100 & 38 & 100 \\
\hline
\end{tabular}

Tabel 8 menunjukkan bahwa lebih dari $50 \%$ responden yang memiliki pendidikan pada tingkat SD mempunayi sikap yang negatif terhadap jamban sehat sedangkan responden dengan pendidikan SMA lebih dari 50\% memiliki sikap yang positif terhadap jamban sehat.

c. Tabulasi Silang Antara Pegetahuan Dan Sikap.

Tabel 9. Tabulasi Silang Antara Pengetahuan Dan Sikap di RT 1 RW 2 Desa Gayaman Mojoanyar Mojokerto

\begin{tabular}{|c|c|c|c|c|c|c|c|}
\hline \multirow{2}{*}{ No. } & \multirow{2}{*}{ Pengetahuan } & \multicolumn{4}{|c|}{ Sikap } & \multicolumn{2}{|}{ TOTAL } \\
\cline { 3 - 6 } & & Positif & \multicolumn{2}{|c|}{ Negatif } & \multicolumn{2}{|c|}{ T } \\
\cline { 3 - 7 } & Baik & 11 & 52,4 & 3 & 17,6 & 14 & 36,8 \\
\hline 1 & Cukup & 7 & 33,3 & 5 & 29,4 & 12 & 31,6 \\
\hline 2 & Kurang & 3 & 14,3 & 9 & 53 & 12 & 31,6 \\
\hline 3 & Jumlah & 21 & 100 & 17 & 100 & 38 & 100 \\
\hline
\end{tabular}

Tabel 9 menunjukkan bahwa lebih dari 50\% responden dengan pengetahuan yang baik tentang jamban sehat, mempunyai sikap yang positif terhadap jamban sehat, sedagkan responden dengan pengetahuan yang kurang tentang jamban sehat, mempunyai sikap yang negatif tentang jamban sehat. Berdasarkan hasil uji statistik chi square menunjukkan bahwa ada hubungan antara pengetahuan dengan sikap keluarga tentang jamban sehat di RT 1 RW 2 Desa Gayaman Mojoanyar Mojokerto, dimana $\mathrm{X}^{2}$ hitung $>\mathrm{X}^{2}$ tabel dengan $\alpha=0,05$, dimana $\mathrm{X}^{2}$ hitung=7,56 dan $\mathrm{X}^{2}$ tabel $=$ 5,591 sehingga Ho ditolak $\left(\mathrm{H}_{1}\right.$ diterima) berarti ada hubungan antara pengetahuan dengan sikap keluarga tentang jamban sehat di RT 1 RW 2 Desa Gayaman Mojoanyar Mojokerto.

E. PEMBAHASAN.

1. Pengetahuan Keluarga Tentang Jamban Sehat.

Faktor-faktor yang mempengaruhi pengetahuan antara lain pendidikan, pekerjaan, umur, minat, pengalaman, kebudayaan lingkungan sekitar, informasi. Hal ini ditunjang dengan data yang diperoleh dari tabel 5 diketahui bahwa mayoritas responden pendidikan 
SD sebanyak 12 orang (100\%) mempunyai pengetahuan kurang. Tidak dapat dipungkiri bahwa makin tinggi pendidikan seseorang semakin mudah pula mereka menerima informasi, dan pada akhirnya makin banyak pula pengetahuan yang dimilikinya. Sebaliknya jika seseorang tingkat pendidikannya rendah, akan menghambat perkembangan sikap seseorang terhadap penerimaan, informasi dan nilai-nilai yang baru diperkenalkan (Mubarrak, 2007). Hal ini mencerminkan dengan tingginya tingkat pendidikan seseorang maka proses penerimaan informasi akan mudah. Dari tabel 5 diketahui bahwa mayoritas responden berumur 25-60 tahun yaitu 13 orang (100\%) mempunyai pengetahuan cukup. Makin tua umur seseorang, maka proses perkembangan akan bertambah baik, akan tetapi pada umur-umur tertentu bertambahnya proses perkembangan mental ini tidak secepat seperti ketika berumur belasan tahun (Elizabet, 1995). Ini menunjukkan pada masa dewasa awal sangat banyak problematika dan tuntutan yang harus dikerjakan oleh para kaum dewasa sehingga secara tidak langsung hal ini akan menurunkan daya konsentrasi.

Hasil penelitian menunjukkan bahwa dari 38 responden yang telah diberi kuesioner dan checklist bahwa sebagian besar 84\% responden menjawab benar tentang pengertian jamban. Menurut Dep Kes RI (2007) pengertian jamban adalah suatu ruangan yang mempunyai fasilitas pembuangan kotoran manusia yang terdiri atas tempat jongkok atau tempat duduk dengan leher angsa atau tanpa leher angsa (cemplung) yang dilengkapi dengan unit penampungan kotoran dan air untuk membersihkannya. Oleh karena itu sesuai dengan tugas keluarga dibidang kesehatan menurut Suprayitno (2004) dalam Danang (2008) diharapkan keluarga mampu memodifikasi lingkungan yang nyaman untuk jaminan kesehatan keluarga. Adapun faktor-faktor yang mempengaruhi pengetahuan, pendidikan berarti bimbingan yang diberikan seseorang pada orang lain terhadap sesuatu hal agar mereka dapat memahami. Tidak dapat dipungkiri bahwa makin tinggi pendidikan seseorang semakin mudah pula mereka menerima informasi, dan pada akhirnya makin banyak pula pengetahuan yang dimilikinya. Sebaliknya jika seseorang tingkat pendidikannya rendah, akan menghambat perkembangan sikap seseorang terhadap penerimaan, informasi dan nilai-nilai yang baru diperkenalkan (Mubarrak, 2007).

Sebagian besar $71 \%$ responden menjawab benar tentang jenis jamban. Jenis Jamban yaitu a) jamban cemplung adalah jamban yang penampungannya berupa lubang yang berfungsi menyimpan dan meresapkan cairan kotoran atau tinja ke dalam tanah dan mengendapkan kotoran ke dasar lubang. Untuk jamban cemplung diharuskan ada penutup agar tidak berbau, b) jamban tangki septik atau leher angsa adalah jamban berbentuk lehar angsa yang penampungannya berupa tangki septik kedap air yang berfungsi sebagai wadah proses penguraian atau dekomposisi kotoran manusia yang dilengkapi dengan resapannya (DepKes RI,2007). Menurut Friedman (1981) dalam Yenichrist (2008) keluarga mempunyai tugas dalam pemeliharaan kesehatan para anggotamya dan saling memelihara yaitu salah satunya adalah mengambil keputusan untuk melakukan tindakan yang tepat.

Sebagian besar 66\% responden menjawab benar tentang syarat jamban. Syarat jamban sehat a) Tidak mencemari sumber air minum (jarak antara sumber air minum dengan lubang penampung minimal 10 meter), b) Tidak berbau, c) Kotoran tidak dapat dijamah oleh serangga dan tikus, d) Tidak mencemari tanah disekitarnya, e) Mudah dibersihkan dan aman digunakan, f) Dilengkapi dinding dan atap pelindung, g) Penerangan dan ventilasi cukup, h) Lantai kedap air dan luas ruangan memadai, i) Tersedia air, sabun, dan alat pembersih (DepKes RI, 2007). Menurut Friedman (1981) dalam Yenichrist (2008) keluarga mempunyai tugas dalam pemeliharaan kesehatan para anggotanya dan saling memelihara salah astu diantara tugas itu adalah mempertahankan hubungan timbal balik antar keluarga dan lembaga-lembaga kesehatan, yang menunjukkan pemanfaatan dengan fasilitas-fasilitas kesehatan yang ada. Oleh sebab itu fungsi keluarga sangat berperan dalam memelihara kesehatan setap anggota keluarganya. 
Lebih dari 50\% menjawab dengan benar pertanyaan tentang cara memelihara jamban. Cara memelihara jamban a). Lantai jamban hendaknya selalu bersih dan tidak ada genangan air, b) Bersihkan jamban secara teratur sehingga ruang jamban dalam keadaan bersih, c) Di dalam jamban tidak ada kotoran yang terlihat, c) Tidak ada serangga, (kecoa, lalat) dan tikus yang berkeliaran, d) Tersedia alat pembersih (sabun, sikat, dan alat pembersih), e) Bila ada kerusakan segera perbaiki (DepKes RI, 2007). Oeh sebab itu tugas keluarga dibidang kesehatan sangat diperlukan menurut Friedman (1981) dalam Yenichirst (2008) diharapkan keluarga dapat mempertahankan suasana di rumah yang menguntungkan kesehatan dan perkembangan kepribadian anggota keluarga.

\section{Sikap Keluarga Tentang Jamban Sehat.}

Menurut Azwar (2005) salah satu faktor yang mempengaruhi dalam pembentukan sikap adalah lembaga pendidikan sebagai suatu sistem mempunyai pengaruh dalam pembentukan sikap dikarenakan keduanya meletakkan dasar konsep moral dalam individu. Pemahaman akan baik dan buruk, garis pemisah antara sesuatu yang boleh dan tidak boleh dilakukan diperoleh dari pendidikan. Sikap merupakan reaksi atau respon seseorang yang masih tertutup terhadap suatu stimulus atau obyek (Notoatmodjo, 2003). Sikap adalah suatu bentuk evaluasi atau reaksi perasaan. Sikap seseorang terhadap suatu obyek adalah perasaan mendukung atau memihak (favorable) maupun perasaan tidak mendukung atau memihak (unfavorable) pada obyek tersebut (Azwar, 2005). Merespon (responding), memberikan jawaban apabila ditanya, mengerjakan dan menyelesaikan tugas dan diberikan adalah suatu indikasi dari sikap. Karena dengan suatu usaha untuk menjawab pertanyaan atau mengerjakan tugas yang diberikan, terlepas dari pekerjaan itu benar atau salah adalah berarti bahwa orang menerima ide tersebut. Sikap responden pada saat penelitian, responden tidak ada yang menolak untuk dijadikan sampel dalam penelitian ini dan juga responden dapat menjawab semua pertanyaan. Dari 18 pertanyaan tidak ada pertanyaan yang tidak dijawab semua pertanyaan dapat dijawab oleh responden.

\section{Tabulasi Silang Antara Pengetahuan Dan Sikap.}

Pada tabel 9 diketahui bahwa paling banyak responden berpengetahuan baik sebanyak 11 orang $(52,4 \%)$ memiliki sikap positif tentang jamban sehat. Hasil uji statistik chi square menunjukkan bahwa ada hubungan antara pengetahuan dengan sikap keluarga tentang jamban sehat di RT 1 RW 2 Desa Gayaman Mojoanyar Mojokerto, dimana X² hitung $>X^{2}$ tabel dengan $\alpha=0,05$, dimana $X^{2}$ hitung=7,56 dan $X^{2}$ tabel $=5,591$ sehingga Ho ditolak $\left(\mathrm{H}_{1}\right.$ diterima) berarti ada hubungan antara pengetahuan dengan sikap keluarga tentang jamban sehat di RT 1 RW 2 Desa Gayaman Mojoanyar Mojokerto. Pengetahuan mengenai suatu obyek yang baru akan menjadi sikap baik apabila sikap tersebut didasari pengetahuan. Jadi pengetahuan seseorang juga bisa berhubungan dengan sikap seseorang, dengan berpengetahuan baik maka kecenderungan sikap orang tersebut baik atau positif (Purwanto, 1999). Komponen Sikap, dalam bagian lain, menurut Alport bahwa sikap mempunyai 3 komponen pokok yaitu: 1) Kepercayaan (keyakinan), ide dan konsep suatu obyek, 2) Kehidupan emosional atau evaluasi emosional terhadap suatu obyek, 3) Kecenderungan untuk bertindak. Ketiga komponen tersebut secara bersama-sama membentuk sikap yang utuh. Dalam penentuan sikap yang utuh ini pengetahuan, berpikir, keyakinan dan emosi memegang peranan penting (Notoatmodjo,2003).

Hubungan pengetahuan dengan sikap keluarga tentang jamban berawal dari tingkat pendidikan dan umur. Semakin tinggi tingkat pendidikan, maka informasi yang didapatkan pun semakin banyak (informasi tentang jamban sehat). Informasi yang didapatkan pun juga dipengaruhi oleh usia, semakin tua usia seseorang maka pengalaman dan pengetahuannya pun semakin luas, apabila pengetahuan seseorang baik, maka orang tersebut mengerti tentang efek samping dari penggunaan jamban yang tidak sehat. Dari 
pengetahuan tentang efek samping penggunaan jamban yang tidak sehat itu maka seseorang tersebut memiliki motivasi untuk penggunaan jamban yang sehat. Dari uraian diatas dapat diilustrasikan hubungan antara pengetahuan dengan sikap tentang jamban sehat.

\section{F. PENUTUP.}

Hasil penelitian menunjukkan bahwa sebagian besar responden memiliki pengetahuan baik tentang jamban sehat yaitu sebanyak 14 orang (36,8\%). Adapun faktorfaktor yang mempengaruhi pengetahuan antara lain pendidikan, pekerjaan, umur, minat, pengalaman, kebudayaan lingkungan sekitar, informasi, sedangkan mayoritas responden memiliki sikap negatif terhadap jamban sehat yaitu sebanyak 17 orang $(44,7 \%)$.

Hasil uji statistik chi square menunjukkan bahwa ada hubungan antara pengetahuan dengan sikap keluarga tentang jamban sehat di RT 1 RW 2 Desa Gayaman Mojoanyar Mojokerto, dimana $\mathrm{X}^{2}$ hitung $>\mathrm{X}^{2}$ tabel dengan $\alpha=0,05$, dimana $\mathrm{X}^{2}$ hitung=7,56 dan $\mathrm{X}^{2}$ tabel $=5,591$ sehingga Ho ditolak $\left(\mathrm{H}_{1}\right.$ diterima) berarti ada hubungan antara pengetahuan dengan sikap keluarga tentang jamban sehat di RT 1 RW 2 Desa Gayaman Mojoanyar Mojokerto.

\section{DAFTAR PUSTAKA.}

Arikunto, Suharsimi. (2006). Prosedur Penelitian Suatu Pendekatan Praktek. Jakarta: Rineka Cipta.

Azwar, Saifuddin. (2005). Sikap manusia teori dan cara pengukurannya. Yogyakarta: Pustaka Pelajar.

Budiarto, Eko. (2001). Biostatistika untuk Kedokteran dan Kesehatan Masyarakat. Jakarta: EGC.

Danang, (2008). Konsep Dasar Keluarga (Online). (http//www.google.com. Diakses 1Maret 2009).

Departemen Kesehatan RI, (2007). Rumah tangga sehat dengan PHBS. Surabaya: Dinas Kesehatan Jatim.

Hidayat. (2003). Riset Keperawatan dan Teknik Penulisan Ilmiah. Jakarta: Salemba Medika.

Hidayat, 2007. Metode Penelitian dan Teknik Analisa Data. Jakarta: Salemba Medika.

Koordinator Program Kartunagari. (2008). Kesehatan Lingkunga (Online). (http//www.google.com Diakses 4 Mei 2009).

Mubarrak, dkk. (2007). Promosi Kesehatan Sebuah Pengantar Proses Belajar Mengajar Dalam Pendidikan. Yogyakarta: Graha Ilmu.

Mujiyanto. (2009). Masalah Sanitasi di Indonesia (Online). (http//www.google.com Diakses 4 Mei 2009).

Notoatmodjo, Soekidjo. (2003). Ilmu Kesehatan Masyarakat. Jakarta: Rineka Cipta.

Notoatmodjo, Soekidjo. (2005). Metodologi Penelitian Kesehatan. Jakarta: Rineka Cipta.

Nursalam, 2003. Konsep dan penerapan Metodologi Penelitian Ilmu Keperawatan Edisi 2. Jakarta: Salemba Medika.

Prasetyo, Sulung. (2008). Visi Kuratif Hambat Perbaikan (Onlline). (http//www.google.com Diakses 4 Mei 2009).

Purwanto, Heri. (1999). Pengantar Perilaku Manusia . Jakarta: EGC.

Wulandari, Catur Ratna. (2009). Bangun Jamban Ubah Kebiasaan (Online). (http//www.google.com Diakses 4 Mei 2009). 